\title{
Projektalapú nyelvoktatás EGYETEMI HALLGATÓK KÖRÉBEN
}

\author{
TÖRÖK JUDIT* - KÉTYI ANDRÁS - HUKNÉ KISS SZILVIA - \\ KOLTÁNYINÉ VADÁSZ VIKTÓRIA - UGRAI ZSUZSANNA - KÓSIK FERENC \\ Budapesti Gazdasági Egyetem Külkereskedelmi Kar
}

A BGE KKK Német Tanszéki Osztálya 2017 őszén bevezette a projektalapú nyelvoktatást. Ehhez kapcsolódóan három féléven át a német szaknyelvet első nyelvként ( $n=65,1$. minta) és második nyelvként $(n=59,2$. minta) tanuló hallgatók körében kutatást végeztünk a problémamegoldó képesség és nyelvtanulási motiváció változásáról, valamint a tanárok közötti együttműködésről. A problémamegoldó feladatnál csak az első minta esetében volt szignifikáns különbség az elő-, illetve az utómérésben $(p<0,001)$. A motiváció az első mintánál nem mutatott szignifikáns különbséget, a második mintánál azonban az utómérésben a belső motivációs tényezőknél szignifikánsan alacsonyabb értéket mértünk $(p<0,005)$. A tanári együttmüködés vonatkozásában megállapítható, hogy a munkaközösség az eltelt három szemeszter során munkacsoportból teammé alakult.

Kulcsszavak: projektalapú nyelvoktatás, problémamegoldás, motiváció, kvantitatív kutatás, fókuszcsoportos interjú

The German Language Section at the BBS FIMB introduced the project based language learning in September 2017. Parallel a mixed research was conducted for three semesters among university students learning German as a first $(n=65,1$. sample) or as a second foreign language $(n=59,2$. sample). The main focuses of our research were on the change in students' problem-solving and motivation and teachers' cooperation. According to our results in pre- and post-measurement, we measured a significant difference in problem-solving only at the 1 . sample $(p<0.001)$. In the case of the motivation, we did not find a significant difference at the 1 . sample. However, the value of the intrinsic motivation of the 2 . sample was significantly lower $(p<0.005)$. Regarding the teacher's cooperation, the working group has become a team during the three semesters.

Keywords: project-based language learning, problem-solving, motivation, quantitative research, focus group interview

Levelező szerző: Török Judit, Budapesti Gazdasági Egyetem Külkereskedelmi Kar, 1165 Budapest,

Diósy Lajos utca 22-24. E-mail: torok.judit@uni-bge.hu 


\section{Bevezetés}

$\mathrm{K}$

utatócsoportunk 2016 óta az Y generáció jellemzőire, partnerintézményünk pozitív tapasztalataira (McDouall-Seidel 2017) és a jelenlegi munkaerőpiaci ela projektalapú oktatás bevezetésén dolgozik. Jelen kutatásunkban arra keressük a választ, hogy a projektalapú nyelvoktatás bevezetésével mennyiben fejlődik az egyetemi hallgatók problémamegoldó képessége és a nyelvtanuláshoz köthető motiváltsága, valamint arra, hogy a hallgatói együttmüködéssel párhuzamosan a tanári együttmüködés is intenzívebbé válik-e a projektalapú nyelvtanítási módszerekkel.

Kutatásunk fókuszát, komplexitását és megtervezettségét tekintve egyedi, mivel tanárok együttműködését, tanulók problémamegoldó képességét és motivációját ilyen mintaszámmal, ennyi mérőeszközzel, elő- és utóméréssel eddig még nem vizsgálták. Ebben közrejátszhat az a tény is, hogy az ilyen kutatások megtervezése és lebonyolítása komoly kihívás (Thomas 2000).

\section{A kutatás elméleti háttere}

\section{A projektalapú (nyelv)tanulás}

Nahalka (1998) szerint a projektoktatás a lehető legkomplexebb módon tesz eleget a konstruktivista pedagógiából fakadó követelményeknek. Ennek is köszönhető, hogy napjainkban egyre szélesebb körben kerül sor a projektmódszer alkalmazására a pedagógia számos területén, így például az óvoda- (Pálfi 2007), a felsőoktatás-(Ollé 2010; BrendelHanke-Macke 2019), és az idegennyelv-pedagógiában (Poór 2001).

A projektorientált tanulást a kortárs idegennyelv-pedagógia a korszerü szaknyelvoktatás egyik fontos módszereként tartja számon (Surkamp 2017). Az idegennyelvoktatás folyamatába integrált projektek jelentős mértékben képesek elősegíteni az olyan cselekvési keretek létrejöttét, amelyek autentikus beszédhelyzeteket indukálnak.

A projektalapú nyelvtanulás során a tanulóknak problémákat kell megoldaniuk vagy egy kimeneti terméket előállítaniuk. Az ilyen projektek során a nyelvtanulók három fö fázisban dolgoznak, először kijelölik a témát, aztán tervet készítenek, illetve kutatást végeznek, végül az eredményt másokkal is megosztják (Moss-Van Duzer 1998). A tanulók a projektekben általában autentikus forrásokat használnak, a tanárnak facilitátor szerepe van, a tanulási célok explicit fogalmazódnak meg, a tanulás kooperatív jellegű, és a munka világában fontos képességek a projekt fázisaiban jelennek meg (Thomas 2000).

\section{A (nyelv)tanulási motiváció jellegzetességei}

A (nyelv)tanulás szempontjából releváns, személyfüggő faktorok közül a motiváció az utóbbi időszak sokat tanulmányozott kutatási témája.

Réthy (2003) szerint a tanuló is aktív részese saját motiválási folyamatának, mely folyamatot a tanulási tevékenység környezeti, szociális és személyes feltételei egyaránt segítik. Csizér és Dörnyei (2005) motivációs énelmélete szerint az idegennyelv-tanulás motivációjának három pillére az ideális idegen nyelvi én, a szükséges idegen nyelvi én és az idegennyelv-tanulási élmények. A tanulói motiváció nagyban függ nemcsak a személyre 
jellemző jegyektől, a tanuló céljaitól, hanem a környezeti ingerektől, a szituációtól is (Beckmann-Heckhausen 2007), így az nem állandó. A motiváció többdimenziós, számos tényezőből álló jelenség, amely időben is változó. A motivációs pszichológia szerint a "flow" (Csíkszentmihályi 2001) vagy a tanulási kedv (Hagenauer 2011) a jó teljesítmény élménye, amikor maga a cselekvés válik jutalomértéküvé.

\section{A problémamegoldó képesség fejlesztése}

Mivel a tanulók a projektek elvégzésénél teamekbe rendeződnek, így egy közös problémamegoldó folyamat zajlik, melyhez - bár feltételezünk egyfajta közös tudást - mindenki saját felkészültségével járul hozzá (Horányi 2007). Ez a tudás az egyes teamtagoknál nem azonos, de egymásnak megfeleltethető, ezért lehet azokat a probléma megoldása során alkalmazni, s ezek a különböző felkészültségek határozzák meg azt, hogy miként zajlik a problémamegoldó folyamat. Fontos ismérve a projektmunkának, hogy a hallgatók felkészültségeiket egyesítve olyan problémamegoldásra képesek, amilyenre egyenként nem. Ebben az integrációban való részesedés a participáció, azaz az aktív részvétel, mely a konstruktivista pedagógia egyik fö alapelve (Nahalka 2002).

A tanulók a projektek során azon emberekre jellemző ismereteket, viselkedési módokat sajátítanak el, akik a valóságban foglalkoznak az adott problémával, és a probléma megoldását fontos értelemmel bíró tevékenységnek tekintik (Molnár 2005).

\section{A tanári együttmüködés a projektalapú nyelvoktatás során}

Az együttműködési formában bekövetkezett változás vizsgálatának alapja a csoport és a team definíciója. A team egy olyan, hierarchiától mentes munkacsoport, mely interaktív és intenzív kölcsönös együttmüködés folyamán közös célokat dolgoz ki és valósít meg a közös kommunikáció és cselekvés során (Francis-Woodcock 2008). A team olyan emberek együttese, akik valamilyen szempontból egynek tekintik magukat, a normákat alakítják és nem statikus szerepeket töltenek be (Handy 2007). Egy teamben fennáll a kritika szükségessége és lehetősége, konstruktív konfliktuskezelés zajlik, a döntéshozatal konszenzusos, nem felülről jövő (Katzenbach-Smith 1993). A team teljesítménye a szinergiának köszönhetően nagyobb, mint az egyének teljesítményének összege, míg a munkacsoport teljesítménye a csoporttagok teljesítményének összege (Belbin 2015). A munkacsoportban az együttmüködés célja általában információcsere és döntéshozatal, továbbá, hogy a tagok egymást segítsék feladataik jobb ellátásában. A teammé válás a fokozódó specializálódás, a szemléletmódváltás, az együttgondolkodás elindulása, a világos célok és a nyitottság következtében valósulhat meg.

\section{A kutatás módszerei, hipotézisei}

\section{A kutatás módszerei, mintája}

Kutatásunkat saját mérőeszközökkel elő- és utóméréssel terveztük meg, az előmérés mindkét minta esetében az első szemeszter elején történt, az utómérés a második szemeszter végén. Az egyes mérési fázisokba a képzésbe belépő teljes, német nyelvet tanuló évfolyamot bevontuk. Az első mintába a németet első idegen nyelvként tanuló hallgatók 
kerültek, a második mintába pedig azok, akik a német nyelvet második nyelvként választják. Előbbiek egyetemi tanulmányaik első szemeszterében, utóbbiak pedig a negyedik szemeszterben tartanak (1. ábra).

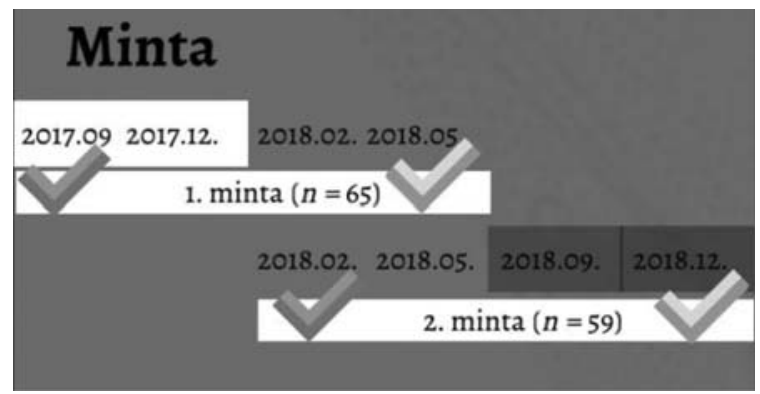

1. ábra: A kutatás tervezett menete (2017-2018)

Az első mérési mintánk $(n=65)$ átlagéletkora 19,31 év volt, a második mérési mintánk ( $n=59)$ átlagéletkora 21,24 év, a nemek aránya pedig közel egyenlően alakult a két mintában, igaz az arányok megfordultak: az 1. mintában a lányok voltak többen (52,9\%), míg a 2. mintában a fiúk (52,5\%).

A kutatásban a hallgatók mellett hét oktató ( 5 nő és 2 férfi) vett részt, átlagéletkoruk 54,5 év volt.

\section{Hipotézisek, méröeszközök}

Hipotéziseink szerint az idegen nyelv autentikus szituációkban való használatával együtt fejlődik a hallgatók problémamegoldó képessége (H1), a nyelvtanulási motivációjuk is nő (H2), továbbá a hallgatói együttmúködésekkel párhuzamosan a tanári együttmüködések is intenzívebbekké válnak (H3). A hipotézisek megválaszolásához saját fejlesztésű mérőeszközökkel gyüjtöttünk adatokat (1. táblázat).

\section{1. táblázat: A kutatás során használt mérőeszközök}

\begin{tabular}{|c|c|}
\hline Hipotézis & Mérőeszközök \\
\hline Problémamegoldó képesség $(\mathrm{H} 1)$ & $\begin{array}{l}\text { Német nyelvű problémamegoldó feladat } \\
\text { Problémamegoldó feladathoz kapcsolódó kérdőív (4 item) }\end{array}$ \\
\hline Motiváció (H2) & $\begin{array}{c}\text { Motivációs kérdőív } \\
\text { 1. minta: } 28 \text { item, Cronbach- } \alpha=0,807 \text { (elő) } / 0,835 \text { (utó) } \\
\text { 2. minta: } 32 \text { item, Cronbach- } \alpha=0,810 \text { (elö) } / 0,772 \text { (utó) }\end{array}$ \\
\hline
\end{tabular}

\section{A kutatás eredményei}

\section{Problémamegoldás}

$\mathrm{A} z$ első minta elő- és utómérési eredményekkel egyaránt rendelkező hallgatói esetében $(n=58)$ egymintás t-próba alapján szignifikáns különbséget $(p<0,001)$ mértünk az el- 


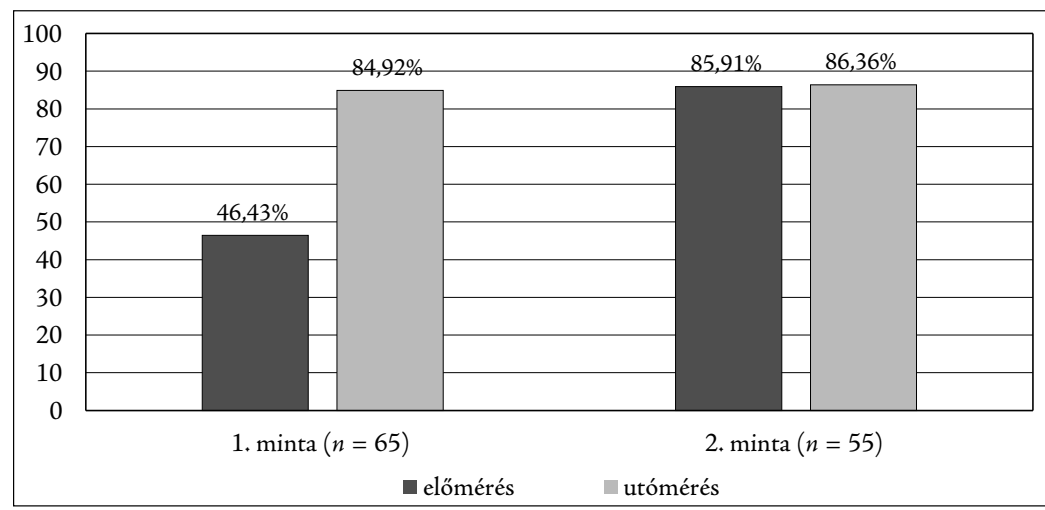

2. ábra: A két minta problémamegoldó feladatának eredményei százalékban

ső szemeszter elején és a második szemeszter végén végzett problémamegoldó feladatok eredményeiben (előmérés: 45,3\%, utómérés: $84,9 \%$ ). A feladat megoldására fordított idő nem tért el a két mérési időpontban, a feladat megoldása az előmérés alkalmával átlagosan 15,4, az utómérésnél 17 percig tartott.

A második minta mindkét mérést megíró hallgatói esetében $(n=50)$ a feladatmegoldásnál nem mértünk szignifikáns különbséget (előmérés: $84,5 \%$, utómérés: $88,5 \%$ ), de a feladat megoldásához szükséges időnél már igen $(p<0,001)$. Míg az előmérésnél átlagosan 18,6 percre volt szükség a megoldáshoz, az utómérésnél csupán 14,8 percre.

A két mintát független kétmintás t-próbával összehasonlítva szignifikáns különbség figyelhető meg az előmérés eredményeinél $(p<0,001)$, az utómérés esetében azonban már nem (2. ábra). Ennek oka lehet, hogy az első mintába az első szemeszterüket megkezdő hallgatók kerültek, s elképzelhető, hogy azért születtek gyengébb eredmények, mert az ilyen típusú problémamegoldó feladat új és szokatlan volt számukra. A második minta hallgatói ezzel szemben, akik már a negyedik szemesztert kezdték meg az előmérés időpontjában, így rendelkezhettek problémamegoldó tapasztalattal más tárgyak esetében. A kitöltési idő is szignifikánsan eltér $(p<0,001)$ az előmérés esetében: míg az első min-

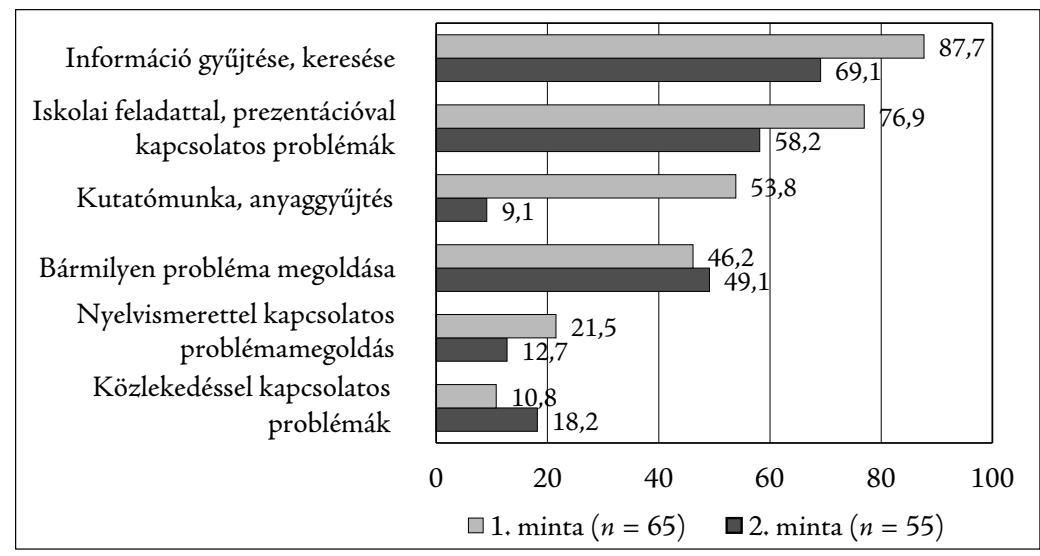

3. ábra: A két minta leggyakoribb problémái a problémamegoldó feladatnál (\%) 
tának átlagosan 15,1 percre volt szüksége a feladat megoldásához, a második minta 18,9 percet szánt a feladatra. Az utómérésnél nem tért el szignifikánsan a feladatra fordított idő, az első minta 16,9 percet dolgozott, a második 14,8 percet.

A problémamegoldó feladathoz kapcsolódó kérdőívben nyitott kérdések segítségével azt is megvizsgáltuk, hogy a hallgatók jellemzően milyen problémákra keresnek választ az internet segítségével, illetve, hogy a kapott problémamegoldó feladat okozott-e nehézségeket számukra. A vizsgálat során összehasonlítottuk a németet első nyelvként (1. minta), illetve második nyelvként tanuló hallgatók (2. minta) válaszait. Mindkét mintában az első három leggyakrabban említett probléma között szerepelt az „Információ gyüjtése, keresése”, „Az iskolai feladattal, prezentációval kapcsolatos problémák”, valamint a „Bármilyen probléma megoldása". A többi probléma előfordulása már eltérően alakult a két mintában (3. ábra).

Konkrétan a problémamegoldó feladatra vonatkozó kérdésnél szignifikáns különbség mutatkozik a két minta között (4. ábra). Míg az 1. minta által adott válaszok 68\%-a jelezte, hogy nem volt problémája a problémamegoldás során, addig a 2. minta válaszainak 29\%-a állította ugyanezt. A problémamegoldás eredményeinél ilyen különbség nem jelentkezett. A nyelvhasználati eredetű problémáknál mutatkozott különbség, míg a 2. minta válaszaiban ez a leggyakoribb (29\%), addig az 1. mintánál ez a probléma marginálisnak tünik (3\%).

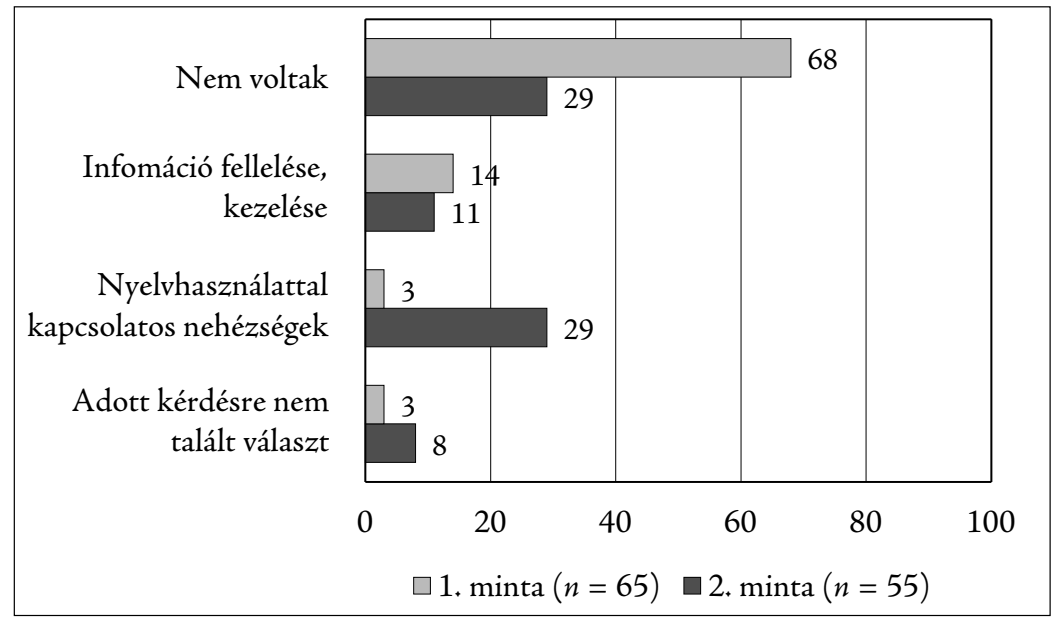

4. ábra: Nehézségek a problémamegoldó feladat megoldása során (\%)

\section{Motiváció}

Második hipotézisünk igazolására ötfokozatú Likert-skálás kérdőívet használtunk, ahol az alacsonyabb értékek kisebb, a magasabb értékek nagyobb motivációt jelentettek. Az első minta esetében 28 kérdést tartalmazott a kérdőív, melyet a második mintánál négy kérdéssel bővítettünk. A kérdőívben a következőkre kerestük a választ:

1. Mit tartanak a hallgatók a nyelvtanulás legfóbb előnyeinek? Milyen tapasztalataik vannak a hallgatóknak általában a nyelvtanulás folyamatáról?

2. Hogyan viszonyulnak a hallgatók a tanári/tanulói visszajelzésekhez? 
3. Hogyan hatnak a hallgatókra a külső motivációs tényezők?

4. Hogyan hatnak a hallgatókra a belső motivációs tényezők?

5. Milyen a hallgatók együttmüködési hajlandósága a nyelvórákon?

Az első mintánál az első kérdőív kitöltésére 2017 szeptemberében került sor, majd 2018 májusában megtörtént az utómérés is. Az első mintánál a mindkét felvétel során kitöltéssel rendelkező hallgatók körében $(n=58)$ egymintás t-próba alapján nem tapasztalható szignifikáns eltérés az elö- és utómérés között.

A második mintánál az első mérést 2018 februárjában, az utómérést 2018 decemberében végeztük. A kérdöívet mindkét alkalommal kitöltő hallgatók körében $(n=47)$ a belső motivációs tényezőket mérő kategóriánál (pl. hogy a nyelvtanulás örömforrás, a tudás gyarapodása motiváló, a kreativitás kibontakoztatásának lehetősége) egymintás t-próba alapján szignifikáns különbséget mértünk $(p<0,005)$. Figyelmeztető jel, hogy a belső motivációs tényezők a kísérlet végére szignifikánsan csökkentek (előmérés: 4,12; utómérés: 3,81).

A két mintát független kétmintás t-próbával összevetve az előmérés során „A nyelvtanulás előnyei” és „A nyelvtanulás folyamata” alskálák esetében tapasztalható szignifikáns különbség $(p<0,001)$ az első minta javára. A $z$ „Együttmüködési hajlandóság” alskála esetén azonban a 2 . minta javára mértünk szignifikáns különbséget $(p<0,001)$ (5. ábra).

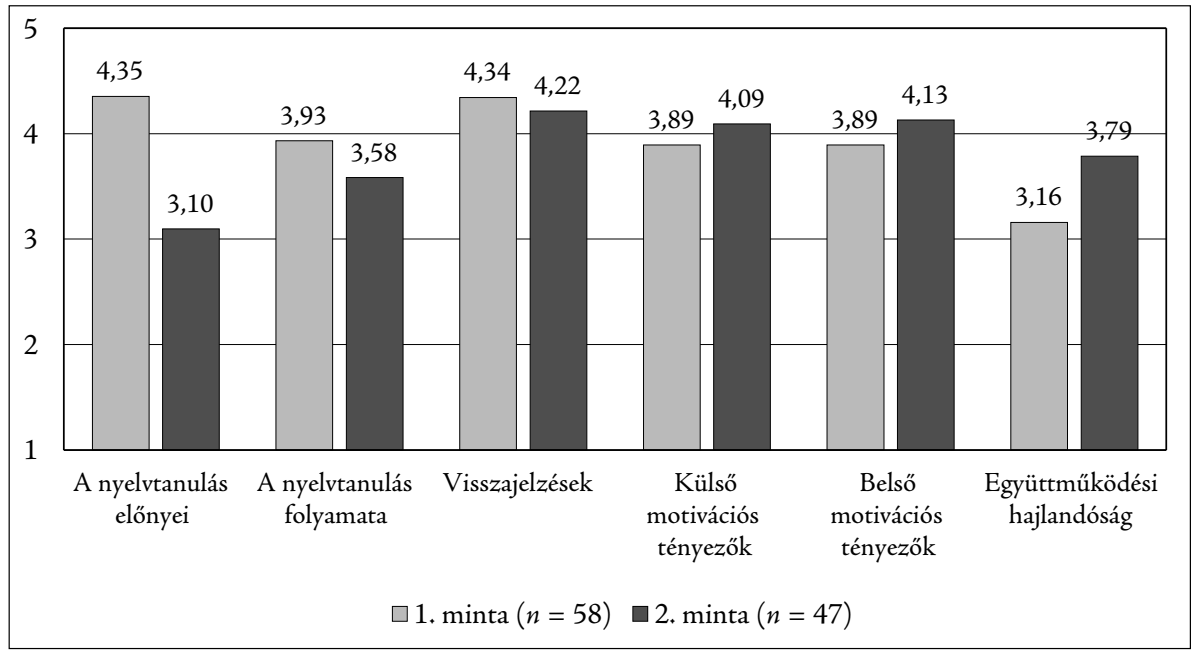

5. ábra: A két minta motivációs értékei az előmérés során (ötfokú skála átlagai, $1=$ Egyáltalán nem értek egyet, $5=$ Teljesen egyetértek)

A $z$ utómérés során már csak az „A nyelvtanulás előnyei” $(p<0,001)$, valamint az "Együttmüködési hajlandóság” ( $p<0,001)$ alskálák esetében mértünk szignifikáns különbséget, előbbinél az 1. minta, utóbbinál a 2. minta javára (6. ábra). 


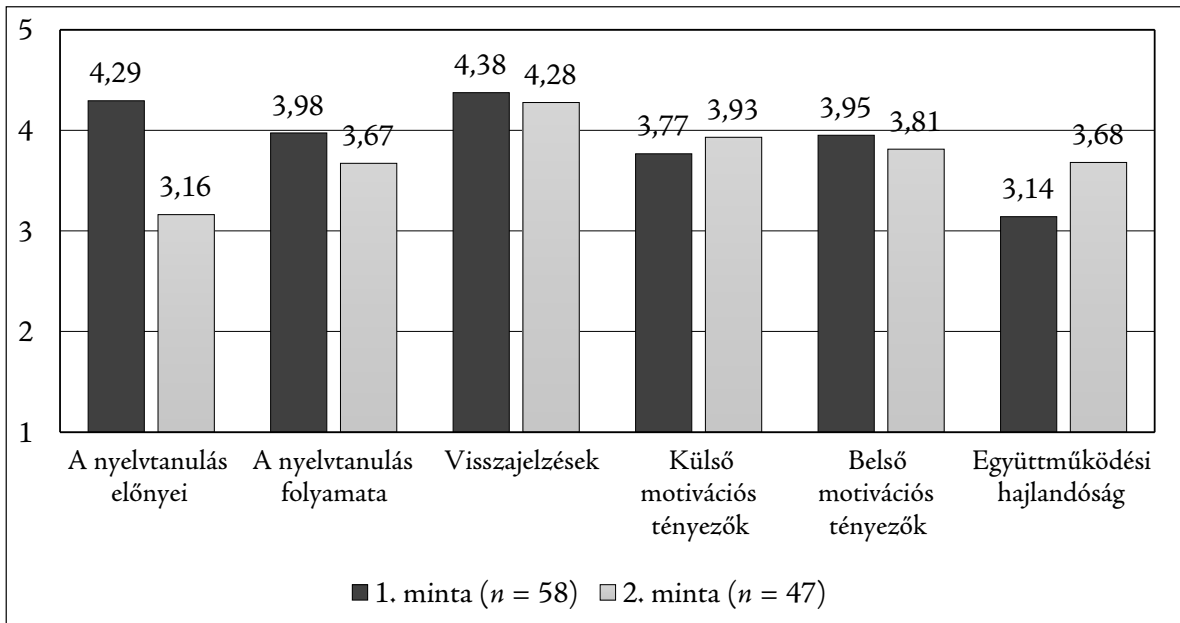

6. ábra: A két minta motivációs értékei az utómérés során (ötfokú skála átlagai, 1 = Egyáltalán nem értek egyet, $5=$ Teljesen egyetértek)

\section{Tanári kérdöív eredmény}

Harmadik hipotézisünk bizonyítására kérdőívet és fókuszcsoportos interjút használtunk. A kérdőíveket a kutatás során az első félév elején (2017. szeptember) és a második félév végén (2018. május), a fókuszcsoportos megkérdezést pedig a harmadik szemeszter folyamán (2018, november) készítettük. A kérdőívek négypontos Likert-skálás, valamint nyitott kérdéseket is tartalmaztak.

Az első félévet megelőző néhány hónapos időszakban (2017. tavaszi szemeszter) elindult együttműködést a stratégia kidolgozása, tananyagkészítési folyamat és a kutatómunka összehangolása jellemezte. A kollégák egyetértettek abban, hogy a megbeszélés, a véleménycsere, a problémák közös megoldása, a tananyaggal járó egyeztetések a tanszéki osztály mindennapjaihoz tartoztak az elmúlt tanév során, s ezt a munkafolyamatot a team tagjai egybehangzóan a legpozitívabban értékelték. A második félévben a tapasztalatcsere és inkább a hallgatói visszajelzéseken és tapasztalatokon alapuló szakmai vita vált hangsúlyossá. A válaszadó kollégák szerint már előfordultak olyan helyzetek is, amelyekben nem lehetett kompromisszumot kötni, és fel kellett adni valamely elképzelést, bár a kollégák ennek ellenére egyértelműen szívesen vettek részt a munkában.

A válaszok szerint az együttmüködés legfőbb hozadéka volt a szakmai diszkusszió, a saját oktatói személyiség fejlődése, a motiváció és az együttműködési készség növekedése, a komfortzóna tágulása, a pedagógiai eszköztár bővülése és a várható output, azaz a problémaalapú tananyag elkészülése. Sikeresen müködik a kollektív fejlesztő tevékenység, strukturáltabb a munka, több az interakció. Hangsúlyt kapott, hogy valami felépült, aminek már régen fel kellett volna. A kollégák véleménye szerint a koncepció, a modulok és az értékelő rendszer gyors kialakítása, a külföldi partnerintézményekkel való eszmecsere és a szakmai elkötelezettség járult hozzá a projektalapú oktatás bevezetéséhez. Sokat fejlődött a szaknyelvoktatási kultúra és nőtt az együttmüködési készségük.

A kollégák az elkövetkezendő szemeszterekben a projektoktatás tartós meggyökerezésére s ezzel együtt kultúraváltásra, a projektfeladatok letisztulására és egy projektgyüj- 
temény megjelenésére számítanak. Fontos cél a tananyag online megjelentetésének lehetősége, hogy az egyéb felsőoktatási intézmények számára is elérhető legyen. Egy kolléga kifejezte aggodalmát, hogy esetleg megjelennek a kisebb konfliktusok, amik megoldás híján ártanak az együttműködésnek. Az egyéb észrevételekben elhangzott a részletesebb hallgatói kérdőívek, illetve koncepcióink folyamatos monitorozásának szükségessége. Fontos kérdések a projektfeladatokra adott jegyek súlya, valamint a kapott osztályzatok egységessége a teamtagok között.

A harmadik félév végén végzett fókuszcsoportos megkérdezésben a kollégák egyetértettek abban, hogy az együttmüködés leghasznosabb eleme a tananyagfejlesztés, a módszertani tapasztalatcsere és a csoportból teammé való átalakulás volt. Egyik legfőbb erősségük az innovációs készség, ami remélhetőleg önfenntartóvá válik. Néhány kolléga a külső elismerés hiánya miatt a jövőben kitűzhető célok tekintetében elkeseredettnek érzi magát, motiváltságuk azonban kitart. További feladatként a kimeneti követelmények és a projektalapú nyelvoktatás összhangjának átgondolását, harmonizációját fogalmazták meg. A teammunka folytatását illetően a kollégák egyhangúlag optimistán nyilatkoztak.

\section{Összegzés}

Kutatásunkban a projektalapú nyelvtanulás lehetséges következményeit vizsgáltuk, különösen fókuszálva a hallgatók problémamegoldó képességének és nyelvtanulási motivációjának változására, valamint a tanári együttmüködések alakulására.

A problémamegoldó feladatnál csak az első minta esetében mértünk szignifikáns különbséget az elö-, illetve az utómérés során elért eredményekben. A két mintát összehasonlítva csak az előmérés során elért eredmények esetében tapasztaltunk szignifikáns eltérést. Vagyis a hipotézisünk, miszerint a projektalapú nyelvtanulás fejleszti a problémamegoldó képességet, csak az egyik minta esetében teljesült. Ugyanakkor itt fontos megjegyezni, hogy az első minta esetében, amely első szemeszterüket megkezdő hallgatókból állt, az előmérés során gyenge eredmények születtek. Elképzelhető, hogy az ilyen típusú problémamegoldó feladat nagyon új és szokatlan volt számukra. A második minta hallgatói ezzel szemben már a negyedik szemeszterben jártak az előmérés során, így rendelkezhettek problémamegoldó tapasztalattal más tárgyak esetében.

A motivációnál az első minta esetében nem találtunk szignifikáns különbséget, a második mintánál azonban a belső motivációs tényezők esetében az utómérésnél szignifikánsan alacsonyabb értéket mértünk, vagyis a projektalapú nyelvtanulás ellenére a kísérlet végére a hallgatók belső motiváció kapcsán mért értékei csökkentek. Lehetséges, hogy a második minta résztvevőit a külső motivációs tényezők, úgymint a projektek értékelése kapcsán a társaktól és a tanártól érkező visszajelzések, valamint a kimeneti követelményeknek történő megfelelési kényszer jobban motiválták, mint a belső motivációs tényezők. De az is elképzelhető, hogy a projektekkel végzett munka olyan sok extra időráfordítást jelentett a résztvevőknek, hogy az órán kívül már nem szerettek volna foglalkozni a nyelvtanulással. A két minta eredményeinek összevetése kapcsán kijelenthetö, hogy az első minta a nyelvtanulás előnyeihez a teljes kísérlet során pozitívabban viszonyult, míg a második mintánál ugyanez az együttmüködési hajlandóság esetében tapasztalható. Lehetséges magyarázatnak tartjuk, hogy a második minta tapasztaltabb hallgatókból állt (átlagéletkoruk két évvel magasabb volt), így számukra az együttmüködés a nyelvtanulás esetében is nagyobb fontossággal bírt, mint az egyéni szempontok. Összességében tehát 
az eredmények alapján azt a hipotézisünket, miszerint a hallgatók a projektmunka következtében motiváltabbá válnak, el kell vetnünk.

A tanári együttmüködés vonatkozásában megállapíthatjuk, hogy munkaközösségünk az eltelt három szemeszter során munkacsoportból teammé alakult. A kérdőívekre adott válaszok és a fókuszcsoportos megkérdezés során elhangzottak egybecsengenek mindazzal, amit a szakirodalom említ a munkacsoport és a team kapcsán (Belbin 2015). A kutatás előtti időszakban csapatunk tagjai együtt, de nem közös célért dolgoztak. Jelenleg azonban a vezetési kompetenciák megoszlanak, a team minden tagja kezdeményezhet, kritikát fogalmazhat meg a munkára vonatkozóan. Közös tudásépítés zajlik, valamennyi résztvevő alakítja a szervezeti kultúrát. Folyamatos az interakció, és fennáll egy olyan kölcsönösség, ami felelősséget is feltételez egymás munkája iránt.

A releváns szakirodalmat áttekintve eredményeinket nem tudjuk általánosítani és más kutatásokkal összevetni, már csak azért sem, mert főleg projektpedagógiai ajánlások, innovatív példák találhatók a hazai és a nemzetközi szakirodalomban ( $M$. Nádasi 2010; Hunya 2010; Torgyik 2012; Rummler 2012). Ugyanakkor egyetértünk Thomas (2000) megállapításával, miszerint a projektalapú tanulás hatása növekedhet, ha az egész oktatási intézményben alkalmazzák azt, ami a jövőbeli kutatások számára megfontolandó lehet.

A hallgatókra vonatkozó hipotézisek (H1 és H2) egyértelmű megválaszolásában segíthet egy harmadik minta vizsgálata, ami jelenleg zajlik, az előmérés megtörtént, az utómérés 2019 decemberében zárul.

\section{IRODALOM}

Beckmann, J. \& Heckhausen, H. (2007) Motivation durch Erwartung und Anreiz. Heidelberg, Springer. pp. 105-142.

Belbin, M. (2015) A team, avagy az együttmüködő csoport. Érd, Edge $2000 \mathrm{Kft}$.

Brendel, S., Hanke U. \& Macke, G. (2019) Kompetenzorienztiert lehren an der Hochschule. Opladen \& Toronto, Verlag Barbara Budrich.

Csikszentmhályi M. (2001) FLOW - Az áramlat - A tökéletes élmény pszichológiája. Budapest, Akadémiai Kiadó.

Csizér, K. \& Dörnyei, Z. (2005) The Internal Structure of Language Learning Motivation and Its Relationship with Language Choice and Learning Effort. Modern Language Journal, Vol. 1. pp. 19-36.

Francis, D. \& Woodcock, M. (2008) Team Metrics: Resources for Measuring and Improving of Team Performance. Ring bound. Amherst, MA, HRD PRess.

Hagenauer, G. (2011) Lernfreude in der Schule. Münster, Waxmann.

Handy, C. (2007) Understanding Organisations. Penguin Books Limited.

Horány Ö. (2007) A kommunikáció mint participáció. Budapest, Typotex.

Hunya M. (2010) Projektmódszer a 21. században II. Új Pedagógiai Szemle, Vol. 60. Nos. 1-2. pp. 148-161.

Katzenbach, J. R. \& Smith, D. K. (1993) The Wisdom of Teams: Creating the Highperformance Organisation. Boston, Harvard Business School.

M. NÁdasi M. (2010) A projektoktatás elmélete és gyakorlata. Budapest, Magyar Tehetségsegítő Szervezetek Szövetsége. 
McDouall, A. \& Seidel, M. (2017) Blended Learning + : Combining Project-based Language Teaching with the Team Protocol Method. https://www.academia.edu/32911871/Blended_ Learning_Combining_Project-based_Language_Teaching_with_the_Team_Protocol_ Method [Letöltve: 2019. 07. 10.]

Molnár Gy. (2005) A probléma alapú tanítás. Iskolakultúra, Vol. 15. No. 10. pp. 31-43.

Moss, D. \& VAn Duzer, C. (1998) Project-based Learning for Adult English Language Learners. ERIC Digest. https://www.ericdigests.org/1999-4/project.htm [Letöltve: 2019. 07. 10.]

Nahalka I. (1998) A konstruktív pedagógia és a tanítás módszerei. In: Hegedưs G., Krajcsovszi J. \& Szászné Virány K. (eds) Projektmódszer I. Kecskemét, Kecskeméti Főiskola TFK. pp. 26-42.

Nahalka I. (2002) Hogyan alakul ki a tudás a gyerekekben? Konstruktivizmus és pedagógia. Budapest, Nemzeti Tankönyvkiadó.

OlLÉ J. (2010) Egy módszer alkonya: a katedrapedagógia végnapjai a felsőoktatásban. In: Doвó I., PerJés I. \& Temesi J. (eds) „Korszerü felsőoktatási pedagógiai módszerek, törekvések". (NFFK Füzetek 5.) Budapest, Budapesti Corvinus Egyetem Közgazdaságtudományi Kar, Nemzetközi Felsőoktatási Kutatások Központja. pp. 22-31.

PÁlfi S. (2007) Projektpedagógia az óvodában. In: Hegedús G. \& Lesku K. (eds) Projektpedagógia - Projektmódszer - X. Kecskemét, Kecskeméti Főiskola TFK. pp. 57-66.

Parment, A. (2009) Die Generation Y - Mitarbeiter der Zukunft: Herausforderung und Erfolgsfaktor für das Personalmanagement. Wiesbaden, Gabler.

Poór Z. (2001) A projektmódszer szerepe az idegen nyelvi nevelésben. In: Hegedüs, G. (ed.): Projektmódszer II. Kecskemét, Kecskeméti Főiskola TFK. pp. 106-111.

RÉTHy E (2003) Motiváció, tanulás, tanitás. Miért tanulunk jól vagy rosszul? Budapest, Nemzeti Tankönyvkiadó.

Rummler, M. (ed.) (2012) Innovative Lebrformen: Projektarbeit in der Hochschule. Weinheim-Basel, Beltz Verlag.

Surkamp, C. (2017) Metzler Lexikon Fremdsprachendidaktik: Ansätze - Methoden Grundbegriffe. 2., akt. und erw. Aufl. Stuttgart, J.B. Metzler Verlag.

Thomas, J. W. (2000) A Review of Research on Project-based Learning. http://www. bobpearlman.org/BestPractices/PBL_Research.pdf [Letöltve: 2019. 07. 10.]

Torgyik J. (2012) A projektmódszer alkalmazásának lehetőségei a felsőoktatásban. In: SÁrdi Cs. (ed.) A felsőoktatás-pedagógia kihivásai a 21. században. Budapest, Eötvös József Kiadó. pp. 123-131.

Tóthné T. T. \& HLÉdik E. (2014) Mit várnak el a nagyvállalatok a pályakezdőktől? In: Nagy I. Z. (ed.) Vállalkozásfejlesztés a XXI. században: IV. tanulmánykötet. Budapest, Óbudai Egyetem Keleti Károly Gazdasági Kar. pp. 387-408.

A cikk a Creative Commons Attribution 4.0 International License (https://creativecommons.org/licenses/ by/4.0/) feltételei szerint publikált Open Access közlemény, melynek szellemében a cikk bármilyen médiumban szabadon felhasználható, megosztható és újraközölhető, feltéve, hogy az eredeti szerző és a közlés helye, illetve a CC License linkje és az esetlegesen végrehajtott módosítások feltüntetésre kerülnek. (SID_1) 